\title{
CARD8 and IL1B Polymorphisms Influence MRI Brain Patterns in Newborns with Hypoxic-Ischemic Encephalopathy Treated with Hypothermia
}

\author{
Katarina Esih ${ }^{1}$ D , Katja Goričar ${ }^{2}$, Zvonka Rener-Primec ${ }^{1,3}$, Vita Dolžan ${ }^{2, *}$ and Aneta Soltirovska-Šalamon ${ }^{3,4, *(\mathbb{D})}$ \\ 1 Division of Paediatrics, Department of Child, Adolescent and Developmental Neurology, \\ University Medical Centre Ljubljana, 1000 Ljubljana, Slovenia; katarina.esih@gmail.com (K.E.); \\ zvonka.renerprimec@kclj.si (Z.R.-P.) \\ 2 Pharmacogenetics Laboratory, Institute of Biochemistry and Molecular Genetics, Faculty of Medicine, \\ University of Ljubljana, 1000 Ljubljana, Slovenia; katja.goricar@mf.uni-lj.si \\ 3 Faculty of Medicine, University of Ljubljana, 1000 Ljubljana, Slovenia \\ 4 Division of Pediatrics, Department of Neonatology, University Medical Centre Ljubljana, \\ 1000 Ljubljana, Slovenia \\ * Correspondence: vita.dolzan@mf.uni-lj.si (V.D.); aneta.soltirovska@kclj.si (A.S.-Š.); \\ Tel.: +38-61-543-7670 (V.D.); Tel.: +38-93-175-5790 (A.S.-Š.)
}

check for updates

Citation: Esih, K.; Goričar, K.; Rener-Primec, Z.; Dolžan, V.; Soltirovska-Šalamon, A. CARD8 and IL1B Polymorphisms Influence MRI Brain Patterns in Newborns with Hypoxic-Ischemic Encephalopathy Treated with Hypothermia. Antioxidants 2021, 10, 96. https:// doi.org/10.3390/antiox10010096

Received: 29 November 2020 Accepted: 8 January 2021 Published: 12 January 2021

Publisher's Note: MDPI stays neutral with regard to jurisdictional clai$\mathrm{ms}$ in published maps and institutional affiliations.

Copyright: (C) 2021 by the authors. Licensee MDPI, Basel, Switzerland. This article is an open access article distributed under the terms and conditions of the Creative Commons Attribution (CC BY) license (https:// creativecommons.org/licenses/by/ $4.0 /)$.

\begin{abstract}
Inflammation and oxidative stress are recognized as important contributors of brain injury in newborns due to a perinatal hypoxic-ischemic (HI) insult. Genetic variability in these pathways could influence the response to $\mathrm{HI}$ and the outcome of brain injury. The aim of our study was to evaluate the impact of common single-nucleotide polymorphisms in the genes involved in inflammation and response to oxidative stress on brain injury in newborns after perinatal $\mathrm{HI}$ insult based on the severity and pattern of magnetic resonance imaging (MRI) findings. The DNA of 44 subjects was isolated from buccal swabs. Genotyping was performed for NLRP3 rs35829419, CARD8 rs2043211, IL1B rs16944, IL1B rs1143623, IL1B rs1071676, TNF rs1800629, CAT rs1001179, SOD2 rs4880, and GPX1 rs1050450. Polymorphism in CARD8 was found to be protective against $\mathrm{HI}$ brain injury detected by MRI overall findings. Polymorphisms in IL1B were associated with posterior limb of internal capsule, basal ganglia, and white matter brain patterns determined by MRI. Our results suggest a possible association between genetic variability in inflammation- and antioxidant-related pathways and the severity of brain injury after $\mathrm{HI}$ insult in newborns.
\end{abstract}

Keywords: inflammation; oxidative stress; polymorphism; hypoxic-ischemic encephalopathy; MRI; newborn

\section{Introduction}

Perinatal hypoxic-ischemic encephalopathy (HIE) results from compromised blood flow and/or oxygen delivery to the newborn baby's brain and is one of the leading causes of long-term neurological disability in children [1]. The incidence of HIE in the developed countries remains around 1-3 per 1000 term newborns over the last decade [1,2]. The most common causes of HIE include placental abruption, cord prolapse, uterine rupture, and breech presentation [3]. The only established therapy for HIE, therapeutic hypothermia (HT), implemented in 2010, improves survival and lowers long-term disability rates, but it is only partially effective [4]. Two methods of cooling have been used in clinical trialsselective head cooling and whole-body cooling. Whole-body cooling is recommended preferentially because it is easier to set up and use, less expensive, provides better access to EEGs, and is more readily available. Although studies suggest that hypothermia exerts a neuroprotective effect by altering several different molecular pathways and affects metabolism, brain perfusion, the release of excitatory amino acids, apoptosis, and antioxi- 
dant and inflammatory processes [5-8], it is not known why some infants benefit from HT while others do not.

The pathophysiological processes after hypoxic-ischemic (HI) insult occur in two main phases: the primary energy failure, followed by the latent period when a brief restoration of blood flow occurs [1,3], and the secondary energy failure [3] during which inflammation and overproduction of reactive oxygen species (ROS) are important for brain injury $[9,10]$. Tissue destruction contributes further to inflammation through activation of inflammasome, an intracellular multiprotein complex. Its main components are NLRP3, CARD8, and caspase- 1 . The activated inflammasome promotes maturation and secretion of inflammatory cytokines, mainly interleukin $1 \beta$ (IL-1 $\beta$ ) and tumor necrosis factor (TNF $\alpha)$ [11], which represent early response cytokines secreted by cells in the central nervous system (CNS) [12]. Parallel to inflammation, an overproduction of ROS leads to oxidative stress that is counteracted by antioxidant enzymes. The most important among them are manganese superoxide-dismutase (MnSOD), glutathione peroxidase (GPX), and catalase (CAT) [13]. MnSOD converts superoxide anion into molecular oxygen and hydrogen peroxide [14], whereas GPX and CAT reduce hydrogen peroxide, preventing the formation of hydroxyl radicals $[15,16]$.

Polymorphisms in inflammatory and antioxidant genes can affect protein activity or gene expression by influencing transcription factor or miRNA binding [17]. Genetic factors could therefore alter the subsequent processes of tissue inflammation and destruction following HIE. Consequently, this could also contribute to the outcome after HIE and lead to different patterns and severity of brain injury $[18,19]$ and could be one of the possible mechanisms for the lower effectiveness of the hypothermia treatment in some patients.

Magnetic resonance imaging (MRI) is used early after the acute HI insult to assess the pattern and severity of brain injury and provides objective measurement of early brain damage that can be at least partially predictive for later neurological outcome [20]. In order to predict better the clinical outcome after HIE, in addition to MRI, serum, cerebrospinal fluid, and other biomarkers have been investigated [21,22]. Neuron-specific enolase serum concentration or phosphorylated axonal neurofilament heavy chain protein concentration was associated with MRI changes after HIE $[21,23]$. IL-1 $\beta$ and Il- 6 concentration was also proposed as a biomarker of long-term outcome after HIE [21,22]. However, the role of genetic variability in the outcome after HIE is not well established. Most studies focused on long-term outcome, especially on susceptibility for cerebral palsy $[18,24-27]$. MTHFR polymorphisms were also proposed as biomarkers of brain injury determined using MRI or other imaging methods [28-30]. Among genes associated with inflammation and oxidative stress, only NOS3 polymorphisms were associated with brain injury on MRI after HIE [31,32], but in these studies, the MRI classification was performed only at two years of age. The association between genetic variability of inflammatory and antioxidant genes and early MRI findings has not been addressed yet.

The aim of our study was to evaluate the association between the severity and a pattern of MRI findings and polymorphisms in genes of antioxidant and inflammatory pathways involved in the pathogenesis after HIE.

\section{Subjects and Methods}

\subsection{Study Population}

Newborns with moderate and severe HIE were retrospectively identified from the electronic database of the neonatal intensive care unit at the University Children's Hospital Ljubljana. Inclusion criteria were as follows: infants born between 2007 and 2019, with $\geq 36$ weeks of gestation and who underwent treatment with therapeutic hypothermia due to perinatal asphyxia ( $5 \mathrm{~min}$ Apgar score $\leq 5, \mathrm{pH} \leq 7.0$, base deficit $\geq 16 \mathrm{mmol} / \mathrm{L}$, or resuscitation $10 \mathrm{~min}$ after birth) [33]. Evidence of moderate or severe encephalopathy was distinguished by the Sarnat and Sarnat clinical scoring system [34]. Whole-body cooling was started within $6 \mathrm{~h}$ after birth and continued for $72 \mathrm{~h}$. After $72 \mathrm{~h}$, the babies were rewarmed gradually to $36.5^{\circ} \mathrm{C}$. Brain MRI was performed in all within the first week 
after birth (between fourth and seventh day) as a part of routine clinical care (therapeutic hypothermia protocol).

Among 84 children who were treated with total body hypothermia at our center, 40 were excluded due to the following reasons: newborns who did not undergo MRI imaging, subjects where informed consent could not be obtained due to death, rejection by parents or legal guardians to participate in the study, or insufficient contact data availability.

\subsection{MR Imaging Protocol}

MRI scans were performed on Siemens 1.5-T Avanto or 3.0-T Trio (Siemens Medical, Erlangen, Germany) scanners. The standard MRI protocol included axial T1-weighted images or inversion recovery-weighted images, T2-weighted images, and diffusion-weighted images. The custom diffusion sequence consisted of $2 \times 2 \times 2 \mathrm{~mm}$ voxels; $9300 \mathrm{~ms}$ repetition time; $96 \mathrm{~ms}$ echo time; $1710 \mathrm{~Hz} / \mathrm{Px}$; and $2 \mathrm{~b}$-values, 0 and 1000. Two reviewers blinded to patient outcomes reviewed all MRIs and classified all images using the score described below. The interobserver variability was estimated, and in case of disagreement, consensus was obtained with a third blinded reviewer.

\subsection{MR Scoring System}

The patterns of brain injury were classified according to the Rutherford classification [35]. The pattern and severity of injury in the following regions were evaluated and scored: posterior limb of internal capsule (PLIC), thalamus and basal ganglia, white matter, and cortex as previously described in the literature [35-37]. Additionally, pattern and severity of brainstem injury were analyzed-lesions at mesencephalon and in pons. An overall assessment was determined by adding up all five regional subscores, and classified as normal, mild, moderate, or severe injury [38]. Subjects were classified as normal if there was no injury seen on MRI. If there were mild, moderate, or severe MRI findings in one, two, or all of the assessed regions, overall assessment was defined as mild, moderate, or severe, respectively. We also transformed the scores into binary variables and compared subjects with normal/mild to subjects with moderate/severe pathological MRI findings.

\subsection{DNA Extraction and Genotyping}

Genomic DNA was extracted from buccal swab samples using QIAamp DNA Mini Kit (Qiagen) according to the manufacturer's instructions. Common single-nucleotide polymorphisms (SNPs) with experimentally or in silico predicted function in antioxidant (SOD2 rs4880, CAT rs1001179, GPX1 rs1050450) and inflammatory (NLRP3 rs35829419, CARD8 rs2043211, IL1B rs1143623, IL1B rs16944, IL1B rs1071676, TNF rs1800629) pathways were genotyped using fluorescent-based competitive allele-specific polymerase chain reaction (KASP, LGC Genomics, UK) according to the manufacturer's instructions.

The study was approved by the Republic of Slovenia National Medical Ethics Committee and informed consent was obtained from all the participants' parents or legal guardians before inclusion in the study.

\subsection{Statistical Analysis}

Median with interquartile range (25-75\%) and frequencies were used to describe continuous and categorical variables, respectively. Dominant genetic model was used in all analyses. Deviation from Hardy-Weinberg equilibrium (HWE) was assessed using the standard $X^{2}$ test. Logistic regression was used to evaluate the association of common SNPs with MRI brain patterns, and odds ratios (ORs) with corresponding 95\% confidence intervals (CIs) were calculated. Fisher's exact test was used for comparison of dependent variables with more than two categories. As nine SNPs were investigated, Bonferroni correction was used to account for multiple comparisons: $p$-values below 0.006 were considered statistically significant, while $p$-values between 0.006 and 0.050 were considered nominally significant. All statistical tests were two-sided. For a polymorphism with minor allele frequency of 0.30 , this study had $80 \%$ power to detect ORs of 5.9 or more. 
Power calculation was conducted by the PS Power and sample size calculations, version 3.0 [39]. The statistical analysis was performed using IBM SPSS Statistics version 21.0 (IBM Corporation, Armonk, NY, USA).

\section{Results}

In total, 44 newborns met all the inclusion criteria. Clinical characteristics of the participants are presented in Table 1 . The median gestational age was 40 (38-40) gestational weeks. The study group consisted of $35(56.8 \%)$ boys and $19(43.2 \%)$ girls (Table 1$)$.

Table 1. Clinical characteristics of 44 newborns with HIE.

\begin{tabular}{ccc}
\hline Clinical Characteristic & Category & N (\%) \\
\hline Gender & Male & $25(56.8)$ \\
& Female & $19(43.2)$ \\
Gestational age [weeks] & Median $(25-75 \%)$ & $40(38-40)$ \\
Birthweight [g] & Median $(25-75 \%)$ & $3300(2800-3492.5)$ \\
Occipital circumference [cm] & Median $(25-75 \%)$ & $34(33-35.5)$ \\
Mode of delivery & Vaginal & $15(34.9)[1]$ \\
& Caesarean section & $25(58.1)$ \\
Apgar score in 5 min & Vacuum extraction & $3(7.0)$ \\
& $\leq 5$ & $35(83.3)$ \\
Apgar score in 10 min & $>5$ & $7(16.7)$ \\
& $\leq 5$ & $18(46.2)[5]$ \\
Sarnat and Sarnat score & $>5$ & $21(53.8)$ \\
& 2 & $21(47.7)$ \\
Neonatal convulsions & 3 & $23(52.3)$ \\
& No, N (\%) & $19(45.2)[2]$ \\
& Yes, N (\%) & $23(54.8)$ \\
\hline
\end{tabular}

Number of subjects with missing data is presented in [] brackets.

MRI overall assessment showed moderate to severe level of injury in 18 patients (41\%) and normal to mild MRI findings in 26 patients (59\%) (Table 2). MRI analysis showed that the rates of moderate to severe damage varied among different brain regions (Table 2). The highest number of injuries was documented in PLIC $(\mathrm{N}=20,45.4 \%)$. Basal ganglia were moderately to severely damaged in 16 patients (36.4\%) and white matter in 18 patients $(41 \%)$. The cortex and the brainstem had the lowest frequency of moderate-severe damage on MRI (10 and 9 patients, respectively) (Table 2). None of the clinical criteria were associated either with the severity of injury on the overall MRI findings (all $p>0.05$ ) or with brain injury patterns (all $p>0.05$ ).

Table 2. MRI brain patterns and the levels of injury according to Rutherford classification [35].

\begin{tabular}{ccc}
\hline MRI Brain Pattern & Category & N (\%) \\
\hline \multirow{3}{*}{ Overall assessment } & Normal & $9(20.5)$ \\
& Mild & $17(38.6)$ \\
& Moderate & $9(20.5)$ \\
& Severe & $9(20.5)$ \\
\hline \multirow{2}{*}{ Basal ganglia } & Normal & $19(43.2)$ \\
& Mild & $9(20.5)$ \\
& Moderate & $11(25.0)$ \\
& Severe & $5(11.4)$ \\
\hline \multirow{2}{*}{ PLIC } & Normal & $24(54.6)$ \\
& Equivocal & $13(29.5)$ \\
& Loss & $7(15.9)$ \\
\hline
\end{tabular}


Table 2. Cont.

\begin{tabular}{|c|c|c|}
\hline MRI Brain Pattern & Category & N (\%) \\
\hline \multirow{4}{*}{ Brainstem } & Normal & $33(75.0)$ \\
\hline & Mild & $2(4.5)$ \\
\hline & Moderate & $5(11.4)$ \\
\hline & Severe & $4(9.1)$ \\
\hline \multirow{4}{*}{ White matter } & Normal & $13(29.5)$ \\
\hline & Mild & $13(29.5)$ \\
\hline & Moderate & $12(27.3)$ \\
\hline & Severe & $6(13.6)$ \\
\hline \multirow{4}{*}{ Cortex } & Normal & $31(70.5)$ \\
\hline & Mild & $3(6.8)$ \\
\hline & Moderate & $3(6.8)$ \\
\hline & Severe & $7(15.9)$ \\
\hline \multicolumn{3}{|c|}{ Legend: MRI = magnetic resonance imaging, PLIC = posterior limb of internal capsule. } \\
\hline \multicolumn{3}{|c|}{ 3.1. Association of Common Polymorphisms with Overall MRI Findings } \\
\hline \multicolumn{3}{|c|}{$\begin{array}{l}\text { The genotype frequencies of common polymorphisms in the antioxidant and inflam- } \\
\text { matory pathways are shown in Table S1. All of the investigated polymorphisms were in } \\
\text { Hardy-Weinberg equilibrium (Table S1). For ILIB rs16944, the polymorphic C allele is } \\
\text { more frequent in European populations and was chosen as the reference allele in further } \\
\text { analyses. }\end{array}$} \\
\hline
\end{tabular}

\subsubsection{Antioxidant Pathway}

When comparing all MRI pattern groups, carriers of at least one polymorphic CAT rs1001179 $\mathrm{T}$ allele were more likely than noncarriers to have a normal MRI according to overall assessment $(p=0.034)$. When we grouped patients with normal-mild and moderate-severe injury together, none of the investigated polymorphisms in the common antioxidant genes showed a statistically significant or nominally significant association with the severity of brain damage on MRI (Table 3).

\subsubsection{Inflammatory Pathway}

Carriers of at least one polymorphic CARD8 rs2043211 T allele were less likely than noncarriers to have severe MRI damage $(p=0.048)$ and moderate-severe damage $(\mathrm{OR}=0.26,95 \% \mathrm{CI}=0.07-0.94, p=0.040)$. Additionally, the polymorphic IL1B $\mathrm{rs} 1143623 \mathrm{C}$ allele showed nominally significant association with increased moderate-severe damage on MRI (OR $=3.78,95 \% \mathrm{CI}=1.06-13.45, p=0.040)$.

\subsection{MRI Brain Patterns}

IL1B rs1143623 showed a nominally significant association with higher damage of basal ganglia according to $\mathrm{MRI}(\mathrm{OR}=3.96,95 \% \mathrm{CI}=1.07-14.67, p=0.039)$.

Two polymorphisms in IL1B were associated with higher PLIC damage: IL1B rs1143623 $(\mathrm{OR}=5.67,95 \% \mathrm{CI}=1.54-20.79, p=0.009)$ and $\mathrm{IL} 1 \mathrm{~B} \mathrm{rs} 16944(\mathrm{OR}=3.71,95 \% \mathrm{CI}=1.06-12.97$, $p=0.040)$. On the other hand, $I L 1 B$ rs1071676 was associated with lower white matter damage $(\mathrm{OR}=0.18,95 \% \mathrm{CI}=0.05-0.68, p=0.011)$ (Table 4). Additionally, CARD8 rs2043211 was associated with lower brainstem and cortex damage $(\mathrm{OR}=0.07,95 \% \mathrm{CI}=0.01-0.66$, $p=0.020$ and $\mathrm{OR}=0.15,95 \% \mathrm{CI}=0.03-0.84, p=0.031$, respectively) (Table S2). All associations were nominally significant.

None of the investigated polymorphisms in antioxidant genes were associated with MRI brain patterns in our study (Table 4, Table S2). 
Table 3. Association of common polymorphisms with overall MRI assessment.

\begin{tabular}{|c|c|c|c|c|c|c|c|c|c|c|}
\hline Gene & SNP & Role & Genotype & Normal & Mild & Moderate & Severe & $p^{*}$ & OR $(95 \%$ CI $) * *$ & $p^{* *}$ \\
\hline \multicolumn{11}{|c|}{ Antioxidant pathway } \\
\hline \multirow[t]{2}{*}{ SOD2 } & rs 4880 & p.Ala16Val & $\mathrm{CC}$ & $2(15.4)$ & $5(38.5)$ & $2(15.4)$ & $4(30.8)$ & & Ref. & \\
\hline & & & $\mathrm{CT}+\mathrm{TT}$ & $7(22.6)$ & $12(38.7)$ & $7(22.6)$ & $5(16.1)$ & 0.804 & $0.74(0.20-2.73)$ & 0.647 \\
\hline \multirow[t]{2}{*}{$C A T$} & rs1001179 & c. $-262 C>T$ & $\mathrm{CC}$ & $2(6.9)$ & $13(44.8)$ & $7(24.1)$ & $7(24.1)$ & & Ref. & \\
\hline & & & $\mathrm{CT}+\mathrm{TT}$ & $7(46.7)$ & $4(26.7)$ & $2(13.3)$ & $2(13.3)$ & 0.034 & $0.39(0.10-1.51)$ & 0.173 \\
\hline \multirow[t]{2}{*}{ GPX1 } & rs1050450 & p.Pro198Leu & $\mathrm{CC}$ & $6(31.6)$ & $6(31.6)$ & $3(15.8)$ & $4(21.1)$ & & Ref. & \\
\hline & & & $\mathrm{CT}+\mathrm{TT}$ & $3(12)$ & $11(44)$ & $6(24)$ & $5(20)$ & 0.441 & $1.35(0.40-4.57)$ & 0.633 \\
\hline \multirow[t]{2}{*}{ NLRP3 } & rs35829419 & p.Gln705Lys & $\mathrm{CC}$ & $6(15.8)$ & $15(39.5)$ & $8(21.1)$ & $9(23.7)$ & & Ref. & \\
\hline & & & $\mathrm{CA}$ & $3(50)$ & $2(33.3)$ & $1(16.7)$ & $0(0)$ & 0.284 & $0.25(0.03-2.32)$ & 0.221 \\
\hline \multirow[t]{2}{*}{ CARD8 } & rs2043211 & p.Cys10Ter & AA & $3(14.3)$ & $6(28.6)$ & $4(19)$ & $8(38.1)$ & & Ref. & \\
\hline & & & $\mathrm{AT}+\mathrm{TT}$ & $6(26.1)$ & $11(47.8)$ & $5(21.7)$ & $1(4.3)$ & 0.048 & $0.26(0.07-0.94)$ & 0.040 \\
\hline \multirow[t]{5}{*}{ IL1B } & rs1143623 & c. $-1560 G>C$ & GG & $7(30.4)$ & $10(43.5)$ & $2(8.7)$ & $4(17.4)$ & & Ref. & \\
\hline & & & $\mathrm{GC}+\mathrm{CC}$ & $2(9.5)$ & $7(33.3)$ & $7(33.3)$ & $5(23.8)$ & 0.115 & $3.78(1.06-13.45)$ & 0.040 \\
\hline & rs16944 & c. $-598 \mathrm{~T}>\mathrm{C}$ & $\mathrm{CC}$ & $7(30.4)$ & $9(39.1)$ & $3(13)$ & $4(17.4)$ & & Ref. & \\
\hline & & & $\mathrm{TC}+\mathrm{TT}$ & $2(9.5)$ & $8(38.1)$ & $6(28.6)$ & $5(23.8)$ & 0.328 & $2.51(0.73-8.63)$ & 0.143 \\
\hline & rs1071676 & c. ${ }^{* 505 G}>\mathrm{C}$ & GG & $1(5.3)$ & $8(42.1)$ & $5(26.3)$ & $5(26.3)$ & & Ref. & \\
\hline \multirow[t]{2}{*}{$T N F$} & rs1800629 & c. $-308 \mathrm{G}>\mathrm{A}$ & GG & $7(22.6)$ & $11(35.5)$ & $8(25.8)$ & $5(16.1)$ & & Ref. & \\
\hline & & & $\mathrm{GA}+\mathrm{AA}$ & $2(15.4)$ & $6(46.2)$ & $1(7.7)$ & $4(30.8)$ & 0.414 & $0.87(0.23-3.26)$ & 0.831 \\
\hline
\end{tabular}

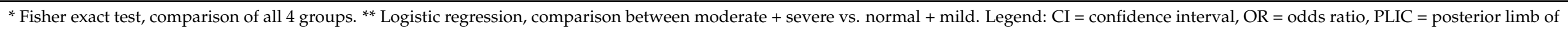
internal capsule, SNP = single-nucleotide polymorphism.

Table 4. The association of polymorphisms with MRI brain patterns.

\begin{tabular}{|c|c|c|c|c|c|c|c|c|c|c|c|c|c|c|}
\hline \multirow[b]{2}{*}{ Gene } & \multirow[b]{2}{*}{ SNP } & \multirow[b]{2}{*}{ Genotype } & \multicolumn{4}{|c|}{ Basal Ganglia } & \multicolumn{4}{|c|}{ PLIC } & \multicolumn{4}{|c|}{ White Matter } \\
\hline & & & $\begin{array}{c}\text { Normal + } \\
\text { Mild } \\
\text { N (\%) }\end{array}$ & $\begin{array}{c}\text { Moderate }+ \\
\text { Severe } \\
\text { N }(\%)\end{array}$ & OR $(95 \% \mathrm{CI})$ & $p$ & $\begin{array}{c}\text { Normal } \\
\text { N (\%) }\end{array}$ & $\begin{array}{l}\text { Equivocal } \\
\text { or Loss } \\
\text { N (\%) }\end{array}$ & OR $(95 \%$ CI $)$ & $p$ & $\begin{array}{c}\text { Normal + } \\
\text { Mild } \\
\text { N (\%) }\end{array}$ & $\begin{array}{c}\text { Moderate + } \\
\text { Severe } \\
\text { N (\%) }\end{array}$ & OR $(95 \%$ CI $)$ & $p$ \\
\hline SOD2 & rs4880 & $\mathrm{CC}$ & $6(46.2)$ & $7(53.8)$ & Ref. & & $6(46.2)$ & $7(53.8)$ & Ref. & & $8(61.5)$ & $5(38.5)$ & Ref. & \\
\hline & & $\mathrm{CT}+\mathrm{TT}$ & $22(71)$ & $9(29)$ & $\begin{array}{c}0.35 \\
(0.09-1.34)\end{array}$ & 0.125 & $18(58.1)$ & 13 (41.9) & $\begin{array}{c}0.62 \\
(0.17-2.28)\end{array}$ & 0.471 & $18(58.1)$ & 13 (41.9) & $\begin{array}{c}1.16 \\
(0.31-4.35)\end{array}$ & 0.831 \\
\hline
\end{tabular}


Table 4. Cont.

\begin{tabular}{|c|c|c|c|c|c|c|c|c|c|c|c|c|c|c|}
\hline \multirow[b]{2}{*}{ Gene } & \multirow[b]{2}{*}{ SNP } & \multirow[b]{2}{*}{ Genotype } & \multicolumn{4}{|c|}{ Basal Ganglia } & \multicolumn{4}{|c|}{ PLIC } & \multicolumn{4}{|c|}{ White Matter } \\
\hline & & & $\begin{array}{l}\text { Normal + } \\
\text { Mild } \\
\text { N (\%) }\end{array}$ & $\begin{array}{c}\text { Moderate + } \\
\text { Severe } \\
\text { N (\%) }\end{array}$ & OR (95\% CI) & $p$ & $\begin{array}{l}\text { Normal } \\
\text { N (\%) }\end{array}$ & $\begin{array}{l}\text { Equivocal } \\
\text { or Loss } \\
\text { N (\%) }\end{array}$ & OR $(95 \%$ CI) & $p$ & $\begin{array}{c}\text { Normal + } \\
\text { Mild } \\
\text { N (\%) }\end{array}$ & $\begin{array}{c}\text { Moderate + } \\
\text { Severe } \\
\text { N (\%) }\end{array}$ & OR $(95 \%$ CI) & $p$ \\
\hline \multirow[t]{2}{*}{$C A T$} & rs1001179 & $\mathrm{CC}$ & 17 (58.6) & $12(41.4)$ & Ref. & & $14(48.3)$ & 15 (51.7) & Ref. & & $16(55.2)$ & $13(44.8)$ & Ref. & \\
\hline & & $\mathrm{CT}+\mathrm{TT}$ & 11 (73.3) & $4(26.7)$ & $\begin{array}{c}0.52 \\
(0.13-2.01)\end{array}$ & 0.340 & $10(66.7)$ & $5(33.3)$ & $\begin{array}{c}0.47 \\
(0.13-1.71)\end{array}$ & 0.250 & $10(66.7)$ & $5(33.3)$ & $\begin{array}{c}0.62 \\
(0.17-2.26)\end{array}$ & 0.464 \\
\hline \multirow[t]{2}{*}{ GPX1 } & rs1050450 & $\mathrm{CC}$ & $13(68.4)$ & $6(31.6)$ & Ref. & & $13(68.4)$ & $6(31.6)$ & Ref. & & $11(57.9)$ & $8(42.1)$ & Ref. & \\
\hline & & $\mathrm{CT}+\mathrm{TT}$ & $15(60)$ & $10(40)$ & $\begin{array}{c}1.44 \\
(0.41-5.07)\end{array}$ & 0.566 & $11(44)$ & $14(56)$ & $\begin{array}{c}2.76 \\
(0.79-9.61)\end{array}$ & 0.111 & $15(60)$ & $10(40)$ & $\begin{array}{c}0.92 \\
(0.27-3.08)\end{array}$ & 0.888 \\
\hline \multirow[t]{2}{*}{ NLRP3 } & rs35829419 & $\mathrm{CC}$ & $23(60.5)$ & 15 (39.5) & Ref. & & $20(52.6)$ & $18(47.4)$ & Ref. & & $21(55.3)$ & $17(44.7)$ & Ref. & \\
\hline & & CA & $5(83.3)$ & $1(16.7)$ & $\begin{array}{c}0.31 \\
(0.03-2.89)\end{array}$ & 0.302 & $4(66.7)$ & $2(33.3)$ & $\begin{array}{c}0.56 \\
(0.09-3.40)\end{array}$ & 0.525 & $5(83.3)$ & $1(16.7)$ & $\begin{array}{c}0.25 \\
(0.03-2.32)\end{array}$ & 0.221 \\
\hline \multirow[t]{2}{*}{ CARD8 } & rs2043211 & AA & $11(52.4)$ & $10(47.6)$ & Ref. & & $10(47.6)$ & $11(52.4)$ & Ref. & & $11(52.4)$ & $10(47.6)$ & Ref. & \\
\hline & & $\mathrm{AT}+\mathrm{TT}$ & 17 (73.9) & $6(26.1)$ & $\begin{array}{c}0.39 \\
(0.11-1.38)\end{array}$ & 0.143 & $14(60.9)$ & $9(39.1)$ & $\begin{array}{c}0.58 \\
(0.18-1.94)\end{array}$ & 0.379 & 15 (65.2) & $8(34.8)$ & $\begin{array}{c}0.59 \\
(0.17-1.97)\end{array}$ & 0.389 \\
\hline \multirow[t]{6}{*}{$I L 1 B$} & rs1143623 & GG & 18 (78.3) & $5(21.7)$ & Ref. & & 17 (73.9) & $6(26.1)$ & Ref. & & $14(60.9)$ & $9(39.1)$ & Ref. & \\
\hline & & $\mathrm{GC}+\mathrm{CC}$ & 10 (47.6) & $11(52.4)$ & $\begin{array}{c}3.96 \\
(1.07-14.67)\end{array}$ & 0.039 & $7(33.3)$ & $14(66.7)$ & $\begin{array}{c}5.67 \\
(1.54-20.79)\end{array}$ & 0.009 & $12(57.1)$ & $9(42.9)$ & $\begin{array}{c}1.17 \\
(0.35-3.89)\end{array}$ & 0.802 \\
\hline & rs16944 & $\mathrm{CC}$ & 17 (73.9) & $6(26.1)$ & Ref. & & $16(69.6)$ & $7(30.4)$ & Ref. & & $13(56.5)$ & $10(43.5)$ & Ref. & \\
\hline & & $\mathrm{TC}+\mathrm{TT}$ & 11 (52.4) & $10(47.6)$ & $\begin{array}{c}2.58 \\
(0.73-9.12)\end{array}$ & 0.143 & $8(38.1)$ & $13(61.9)$ & $\begin{array}{c}3.71 \\
(1.06-12.97)\end{array}$ & 0.040 & $13(61.9)$ & 8 (38.1) & $\begin{array}{c}0.80 \\
(0.24-2.67)\end{array}$ & 0.717 \\
\hline & rs1071676 & GG & $10(52.6)$ & 9 (47.4) & Ref. & & $9(47.4)$ & $10(52.6)$ & Ref. & & 7 (36.8) & $12(63.2)$ & Ref. & \\
\hline & & $\mathrm{GC}+\mathrm{CC}$ & $18(72)$ & $7(28)$ & $\begin{array}{c}0.43 \\
(0.12-1.51)\end{array}$ & 0.190 & $15(60)$ & $10(40)$ & $\begin{array}{c}0.60 \\
(0.18-2.00)\end{array}$ & 0.406 & $19(76)$ & $6(24)$ & $\begin{array}{c}0.18 \\
(0.05-0.68)\end{array}$ & 0.011 \\
\hline \multirow[t]{2}{*}{$T N F$} & rs1800629 & GG & $20(64.5)$ & $11(35.5)$ & Ref. & & $17(54.8)$ & $14(45.2)$ & Ref. & & $18(58.1)$ & $13(41.9)$ & Ref. & \\
\hline & & $\mathrm{GA}+\mathrm{AA}$ & $8(61.5)$ & $5(38.5)$ & $\begin{array}{c}1.14 \\
(0.30-4.33)\end{array}$ & 0.851 & 7 (53.8) & $6(46.2)$ & $\begin{array}{c}1.04 \\
(0.28-3.82)\end{array}$ & 0.952 & $8(61.5)$ & $5(38.5)$ & $\begin{array}{c}0.87 \\
(0.23-3.26)\end{array}$ & 0.831 \\
\hline
\end{tabular}

Legend: $\mathrm{CI}=$ confidence interval, $\mathrm{OR}=$ odds ratio, $\mathrm{PLIC}=$ posterior limb of internal capsule, $\mathrm{SNP}=$ single-nucleotide polymorphism. 


\section{Discussion}

The present study investigated the association of the common polymorphisms in antioxidant and inflammatory genes with HI-related brain injury in newborns. The most important findings were that polymorphism in CARD 8 was protective in regard to $\mathrm{HI}$ brain injury based on the MRI overall findings, and that the polymorphisms in IL1B were associated with PLIC, basal ganglia, and white matter MRI abnormalities.

The immune system plays an important role in brain ischemia [40] and inflammasomes are highly expressed in the CNS. An important inflammasome component is CARD8. In our study, CARD8 rs2043211 was associated with lower overall rates of brain injury and lower brainstem and cortex damage after HIE in newborns treated with HT. To the best of our knowledge, CARD8 and its genetic variability had previously not been studied in terms of outcome following HIE. However, as CARD8 inhibits caspase 1-dependent secretion of IL- $1 \beta$ and activation of nuclear factor NF- $\mathrm{KB}$ signaling and thus reduces the inflammatory response [41-43], it could contribute to brain injury patterns. Genetic factors could influence the role of CARD8, but the function of the CARD8 rs2043211 is not fully understood. Up to now it has been known that the SNP rs2043211 results in an A to $\mathrm{T}$ transversion that leads to a premature stop codon and produces a truncated CARD8 protein [41,43-45] The truncated CARD8 cannot inhibit NF-KB signaling, which results in constitutive production of IL- $1 \beta$ and inflammation $[43,45]$. This seems to be contrary to our findings, as CARD8 rs2043211 had a protective role in our study. However, due to alternative splicing, CARD8 has five known mRNA isoforms that differ in the $\mathrm{N}$-terminal sequence [43].Therefore, the functional consequences of rs2043211 differ among transcripts: in some transcripts, the SNP introduces a stop codon, while in others, it changes the amino acid and affects mRNA stability [43]. The functional role of these isoforms is not yet clear, but it could help explain the contradictory results as the transcripts may vary among the different biological processes [43].

The results of studies on the association between the CARD8 rs2043211 polymorphism and susceptibility to various diseases are not concordant. Consistent with our results, rs2043211 was associated with a protective role in various diseases where inflammation plays an important role: polycystic ovary syndrome [46], inflammatory bowel disease [47], and Crohn's disease $[45,48]$. Moreover, minor rs2043211 T allele had a protective effect in ischemic stroke [41]. Contrary to these findings, in other studies the minor allele was also associated with a higher risk of Alzheimer's disease in women [49] and with gout [50]. Additionally, studies suggest that decreased activity of CARD8 may delay apoptosis [48,51]. Considering that apoptosis is a key part of the prolonged cell death in $\mathrm{HI}$ insult, this could explain the decreased risk of brain injury in hypoxic-ischemic events for CARD8 rs2043211 $\mathrm{T}$ allele. Further studies are therefore needed to determine the role of CARD8 genetic variability in inflammation. Inflammasomes can be differentially regulated in different tissues. Therefore, it is necessary to evaluate how CARD8 acts in different cell types and brain regions, considering different pathologic processes at the same time [40]. According to the Human Protein Atlas data [52,53], CARD8 has low tissue specificity, also in the brain, but better characterization of different transcripts could help elucidate the specific role of CARD8 genetic variability in outcome after HIE.

The second important result in our study was that IL1B polymorphisms were associated with different brain MRI abnormalities. IL- $1 \beta$ is released as a result of inflammasome activation. In our study, promoter IL1B rs1143623 polymorphism was associated with more moderate-severe abnormalities in overall MRI assessment, and newborns with at least one polymorphic allele were more prone to basal ganglia and PLIC injuries based on MRI pattern. Furthermore, promoter IL1B rs16944 polymorphism was also associated with more PLIC abnormalities, while IL1B rs1071676 located in the $3^{\prime}$ untranslated region was associated with less white matter abnormalities.

IL-1 $\beta$ is a proinflammatory cytokine expressed by various brain cells [54]. It is involved in neuroinflammation and neurodegeneration after HIE $[27,55,56]$. In previous studies, rs16944 was associated with increased risk for developing cerebral palsy after 
HIE [27] and increased risk of periventricular leukomalacia after HI insult [57], consistent with our results. IL1B rs16944 can affect transcription of the IL1B gene as it modifies binding of transcriptional factors [27]. It was associated with increased IL-1 $\beta$ secretion [58] and serum IL-1 $\beta$ levels [59], which could contribute to the observed role of rs16944 after HIE. Additionally, rs16944 was associated with various diseases, including mental disorders and brain activity: hippocampal sclerosis [60], metabolic activity in the dorsolateral prefrontal cortex [61], and grey matter deficits in bipolar disorder [61]. IL1B rs1143623 also affects transcription factor binding and serum IL-1 $\beta$ levels [59]. In previous studies it was mostly investigated in various cancers, but recent meta-analysis suggests it does not importantly affect the overall cancer risk [62]. On the other hand, IL1B rs1143623 was associated with Alzheimer's disease pathology [63] and response to biological treatment in psoriasis [64]. The role of IL1B rs1071676 is not well established, but it could affect miRNA binding [65], and it was associated with response to anti-TNF therapy [66]. Previous findings are therefore consistent with our results as we have also shown an association between IL1B rs1143623 and IL1B rs16944 and more basal ganglia and PLIC abnormalities based on MRI pattern.

Central grey matter damage following perinatal $\mathrm{HI}$ insult is closely related to the severity of the motor impairment, and studies showed that injury to the basal gangliathalamus is a predictor of cerebral palsy, and abnormal PLIC signal intensity on early MRI was associated with the inability to walk independently by two years [67]. So far it is not known how and to which extent polymorphisms have an influence in different regions of the brain, therefore we cannot explain why some IL1B polymorphisms have a region-specific effect. However, some studies have already investigated the effect of ILIB polymorphisms on specific brain regions by brain MRI. IL1B rs16944 allele carriers had smaller hippocampal regions, lower prefrontal functional connectivity, and larger white matter hyperintensity [68]. According to our study, a plausible explanation is that the lesion pattern, which resulted from the pathophysiological mechanism of the HI event, may be responsible for the regional activation of the inflammatory pathway including IL-1 $\beta$.

In this study, polymorphisms in the common antioxidant genes involved in the processes after HI did not have a major role in brain injury patterns. Only CAT rs1001179 T allele had a protective effect on MRI brain injury. This polymorphism alters the transcription factor binding site in the promoter region [17], however, its functional effect is not clear [18]. In our previous study in children with HIE who did not undergo hypothermia, it was associated with the development of cerebral palsy [18]. We could thus hypothesize the role of CAT could be affected by the hypothermia treatment. Some studies have also shown a protective effect of the minor rs1001179 T allele: it was associated with the later presentation of neurological manifestations of Wilson's disease [69] and with decreased acoustic neuroma risk [70]. None of the other common polymorphisms in the antioxidant pathway were associated with MRI overall assessment or MRI pattern in our study population.

Our study demonstrated the association of some polymorphisms in the antioxidant and inflammatory pathways and MRI abnormalities in newborns after $\mathrm{HI}$ insult. In a newborn, HI insult during the phase of primary energy failure and the impairment of cerebral blood flow entails inadequate supply of oxygen and metabolic substrate to the brain tissue, which initiates a cascade of cellular injury [3]. The secondary energy failure phase after $\mathrm{HI}$ insult when reperfusion occurs is multifactorial and is characterized by inflammation, cytotoxic oedema, mitochondrial failure, and generation of ROS and free radicals and programmed cell death [3]. The injured brain stimulates innate immune response through activation of microglia and circulating leukocytes which release various molecules including ROS, proteases, and proinflammatory cytokines. The severity of these reactions has been related to cell death and severe neurologic disabilities [71]. HT has been shown to reduce apoptosis, which is an energy-demanding process: higher temperature means higher metabolic rate and faster cellular death. Furthermore, lowering the temperature decreases the metabolic rate of all cell processes and so spares some 
mitochondrial energy production for reparative mechanisms and survival of cells [5]. During $72 \mathrm{~h}$ of HT, more neurons might have a chance to repair the damage of inflammatory and oxidative processes. This would explain reduced disability in children treated with HT after HIE, especially whole-body HT. However, some children among them still have poor outcome $[6,20]$. The latent period in which HT is most effective is also related to the severity of HIE, as severe HIE may shorten the period and consequently the length of the therapeutic window [72]. Interindividual variability in response to HT may therefore depend on the duration of the ischemic event, the extent of the injury, or genetic factors that alter the subsequent processes of tissue inflammation and antioxidant response following HIE. In our study we found that in addition to HI event, genetic factors may affect the development and patterns of brain injury. In this regard, our results emphasize that genetic modification of the inflammatory response after $\mathrm{HI}$ insult is more important for severity of brain injury compared to polymorphisms in the antioxidant pathway.

The strength of our study is that, to the best of our knowledge, it is the first study using a pathway-based approach to address the relationship between some of the inflammation and antioxidant polymorphisms in newborns with $\mathrm{HI}$ insult. We were able to demonstrate the association between the common antioxidant and inflammatory gene polymorphisms and MRI brain patterns and the severity of brain damage after HIE. Nevertheless, the results should be interpreted with caution due to retrospective study design and small study sample, which are the main limitations of our study. The retrospective study design prevented us from including all newborns in our medical center treated with HT in the newborn period as some newborns died, several parents did not agree to take part in the study, and for some, contact data were not available. So, with the limited number, the statistical power to detect the association may have been impaired. Therefore, negative results were difficult to address, as we could not detect the polymorphisms' potential smaller effect sizes. Additional, more comprehensive studies are therefore needed to validate these results. Furthermore, our study did not include newborns from the era before hypothermia. Moreover, in future studies it could be of interest to analyze association between polymorphisms in the antioxidant and inflammatory pathways and the long-term outcome after $\mathrm{HI}$ insult in the newborn period since persistent inflammation and epigenetic changes which are crucial in brain repairing and regenerating have been proposed as mechanisms of long-lasting injurious processes.

\section{Conclusions}

The results of this study present a possible association of the polymorphisms in inflammation and the antioxidant pathway with the risk severity of brain injury after $\mathrm{HI}$ insult in the newborn period. CARD8 rs2043211, IL1B rs1143623, IL1B rs16944, IL1B rs1071676, and CAT rs1001179 were associated with MRI brain abnormalities. The results of this study are the first indication that individual genetic differences in inflammation and oxidative stress pathways may be involved in the pathogenesis of $\mathrm{HI}$ insult in the newborn period.

Supplementary Materials: The following are available online at https:/ /www.mdpi.com/2076-392 1/10/1/96/s1, Table S1: Genotype frequencies of selected polymorphisms, Table S2: The association of polymorphisms with brainstem and cortex damage.

Author Contributions: Conceptualization, A.S.-̌̌. and Z.R.-P.; Methodology, K.G., V.D., and A.S.-Š.; Software, K.G.; Validation, Z.R.-P., and V.D.; Formal Analysis, K.G.; Investigation, K.E.; Resources, A.S.-Š.; Data Curation, K.E.; Writing—Original Draft Preparation, K.E.; Writing—Review \& Editing, A.S.-Š.; Visualization, K.G.; Supervision, Z.R.-P. and V.D. All authors have read and agreed to the published version of the manuscript.

Funding: Researchers from the following two research programs financed by Slovenian Research Agency ARRS were involved in the study: Molecular mechanisms of regulation of cellular processes related to some human diseases-P1-0170, and Etiology, early detection, and treatment of diseases in 
childhood and adolescence-P3-0343. The publication costs were financed by the Slovenian Research Agency ARRS research program No. P1-0170.

Institutional Review Board Statement: The study was conducted according to the guidelines of the Declaration of Helsinki, and approved by the Slovenia's National Medical Ethics Committee (129/07/14, 11 August 2014).

Informed Consent Statement: Informed consent was obtained from all subjects involved in the study.

Data Availability Statement: All the data is presented within the article and in supplementary material. Any additional information is available on request from the corresponding author.

Acknowledgments: We are grateful to Derganc M. for the introduction of hypothermia treatment in Slovenia and collecting a patient's database. We are grateful to Martinez-Biarge M. for additional education, training, and revising MRI scoring according to Rutherford classification. Our gratitude goes to all study participants, medical staff, and research scientists who took part in the present study.

Conflicts of Interest: The authors declare no conflict of interest.

\section{References}

1. Lai, M.-C.; Yang, S.-N. Perinatal Hypoxic-Ischemic Encephalopathy. J. Biomed. Biotechnol. 2011, 2011, 609813. [CrossRef]

2. Douglas-Escobar, M.; Weiss, M.D. Hypoxic-ischemic encephalopathy: A review for the clinician. JAMA Pediatr. 2015, 169, 397-403. [CrossRef] [PubMed]

3. Allen, K.A.; Brandon, D.H. Hypoxic Ischemic Encephalopathy: Pathophysiology and Experimental Treatments. Newborn Infant Nurs. Rev. 2011, 11, 125-133. [CrossRef] [PubMed]

4. Davidson, J.O.; Wassink, G.; van den Heuij, L.G.; Bennet, L.; Gunn, A.J. Therapeutic Hypothermia for Neonatal Hypoxic-Ischemic Encephalopathy-Where to from Here? Front. Neurol. 2015, 6. [CrossRef] [PubMed]

5. Joy, R.; Pournami, F.; Bethou, A.; Bhat, V.B.; Bobby, Z. Effect of therapeutic hypothermia on oxidative stress and outcome in term neonates with perinatal asphyxia: A randomized controlled trial. J. Trop. Pediatr. 2013, 59, 17-22. [CrossRef] [PubMed]

6. Hakobyan, M.; Dijkman, K.P.; Laroche, S.; Naulaers, G.; Rijken, M.; Steiner, K.; van Straaten, H.L.M.; Swarte, R.M.C.; Ter Horst, H.J.; Zecic, A.; et al. Outcome of Infants with Therapeutic Hypothermia after Perinatal Asphyxia and Early-Onset Sepsis. Neonatology 2019, 115, 127-133. [CrossRef] [PubMed]

7. Sutcliffe, I.T.; Smith, H.A.; Stanimirovic, D.; Hutchison, J.S. Effects of moderate hypothermia on IL-1 beta-induced leukocyte rolling and adhesion in pial microcirculation of mice and on proinflammatory gene expression in human cerebral endothelial cells. J. Cereb. Blood Flow Metab. 2001, 21, 1310-1319. [CrossRef]

8. Shi, J.; Dai, W.; Kloner, R.A. Therapeutic Hypothermia Reduces the Inflammatory Response Following Ischemia/Reperfusion Injury in Rat Hearts. Ther. Hypothermia Temp. Manag. 2017, 7, 162-170. [CrossRef]

9. Del Arco, L.; Alonso-Alconada, D. Current Research in Neonatal Hypoxic-Ischemic Anti-Inflammatory Therapeutics. EC Paediatr. 2018, 73, 168-170.

10. Nair, J.; Kumar, V.H.S. Current and Emerging Therapies in the Management of Hypoxic Ischemic Encephalopathy in Neonates. Children 2018, 5, 99. [CrossRef]

11. Schroder, K.; Tschopp, J. The inflammasomes. Cell 2010, 140, 821-832. [CrossRef] [PubMed]

12. Liu, F.; McCullough, L.D. Inflammatory responses in hypoxic ischemic encephalopathy. Acta Pharmacol. Sin. 2013, 34, 1121-1130. [CrossRef]

13. Volpe, J.J. Volpe's Neurology of the Newborn; Elsevier: Amsterdam, The Netherlands, 2018.

14. Younus, H. Therapeutic potentials of superoxide dismutase. Int. J. Health Sci. 2018, 12, 88-93.

15. Lubos, E.; Loscalzo, J.; Handy, D.E. Glutathione peroxidase-1 in health and disease: From molecular mechanisms to therapeutic opportunities. Antioxid. Redox Signal 2011, 15, 1957-1997. [CrossRef] [PubMed]

16. Nandi, A.; Yan, L.-J.; Jana, C.K.; Das, N. Role of Catalase in Oxidative Stress- and Age-Associated Degenerative Diseases. Oxid. Med. Cell. Longev. 2019, 2019, 9613090. [CrossRef] [PubMed]

17. Forsberg, L.; Lyrenäs, L.; de Faire, U.; Morgenstern, R. A common functional C-T substitution polymorphism in the promoter region of the human catalase gene influences transcription factor binding, reporter gene transcription and is correlated to blood catalase levels. Free Radic. Biol. Med. 2001, 30, 500-505. [CrossRef]

18. Esih, K.; Goricar, K.; Dolzan, V.; Rener-Primec, Z. The association between antioxidant enzyme polymorphisms and cerebral palsy after perinatal hypoxic-ischaemic encephalopathy. Eur. J. Paediatr. Neurol. EJPN Off. J. Eur. Paediatr. Neurol. Soc. 2016, 20, 704-708. [CrossRef]

19. Bhalala, U.S.; Koehler, R.C.; Kannan, S. Neuroinflammation and neuroimmune dysregulation after acute hypoxic-ischemic injury of developing brain. Front. Pediatr. 2015, 2, 144. [CrossRef] 
20. Rusli, E.R.M.; Ismail, J.; Wei, W.S.; Ishak, S.; Jaafar, R.; Zaki, F.M. Neonatal hypoxic encephalopathy: Correlation between post-cooling brain MRI findings and 2 years neurodevelopmental outcome. Indian J. Radiol. Imaging 2019, 29, 350-355. [CrossRef]

21. Douglas-Escobar, M.; Weiss, M.D. Biomarkers of hypoxic-ischemic encephalopathy in newborns. Front. Neurol. 2012, 3, 144. [CrossRef]

22. Ramaswamy, V.; Horton, J.; Vandermeer, B.; Buscemi, N.; Miller, S.; Yager, J. Systematic review of biomarkers of brain injury in term neonatal encephalopathy. Pediatr. Neurol. 2009, 40, 215-226. [CrossRef] [PubMed]

23. Douglas-Escobar, M.; Yang, C.; Bennett, J.; Shuster, J.; Theriaque, D.; Leibovici, A.; Kays, D.; Zheng, T.; Rossignol, C.; Shaw, G.; et al. A pilot study of novel biomarkers in neonates with hypoxic-ischemic encephalopathy. Pediatr. Res. 2010, 68, 531-536. [CrossRef] [PubMed]

24. Esih, K.; Goricar, K.; Dolzan, V.; Rener-Primec, Z. Antioxidant polymorphisms do not influence the risk of epilepsy or its drug resistance after neonatal hypoxic-ischemic brain injury. Seizure 2017, 46, 38-42. [CrossRef] [PubMed]

25. Sun, L.; Xia, L.; Wang, M.; Zhu, D.; Wang, Y.; Bi, D.; Song, J.; Ma, C.; Gao, C.; Zhang, X.; et al. Variants of the OLIG2 Gene are Associated with Cerebral Palsy in Chinese Han Infants with Hypoxic-Ischemic Encephalopathy. Neuromol. Med. 2019, 21, 75-84. [CrossRef]

26. Wang, H.; Xu, Y.; Chen, M.; Shang, Q.; Sun, Y.; Zhu, D.; Wang, L.; Huang, Z.; Ma, C.; Li, T.; et al. Genetic association study of adaptor protein complex 4 with cerebral palsy in a Han Chinese population. Mol. Biol. Rep. 2013, 40, 6459-6467. [CrossRef]

27. Torres-Merino, S.; Moreno-Sandoval, H.N.; Thompson-Bonilla, M.D.R.; Leon, J.A.O.; Gomez-Conde, E.; Leon-Chavez, B.A.; Martinez-Fong, D.; Gonzalez-Barrios, J.A. Association Between rs3833912/rs16944 SNPs and Risk for Cerebral Palsy in Mexican Children. Mol. Neurobiol. 2019, 56, 1800-1811. [CrossRef]

28. Marseglia, L.M.; Nicotera, A.; Salpietro, V.; Giaimo, E.; Cardile, G.; Bonsignore, M.; Alibrandi, A.; Caccamo, D.; Manti, S.; D'Angelo, G.; et al. Hyperhomocysteinemia and MTHFR Polymorphisms as Antenatal Risk Factors of White Matter Abnormalities in Two Cohorts of Late Preterm and Full Term Newborns. Oxid. Med. Cell. Longev. 2015, 2015, 543134. [CrossRef]

29. Calkavur, S.; Akisu, M.; Olukman, O.; Balim, Z.; Berdeli, A.; Cakmak, B.; Koroglu, O.; Yalaz, M.; Kultursay, N. Genetic factors that influence short-term neurodevelopmental outcome in term hypoxic-ischaemic encephalopathic neonates. J. Int. Med. Res. 2011, 39, 1744-1756. [CrossRef]

30. Harteman, J.C.; Groenendaal, F.; Benders, M.J.; Huisman, A.; Blom, H.J.; de Vries, L.S. Role of thrombophilic factors in full-term infants with neonatal encephalopathy. Pediatr. Res. 2013, 73, 80-86. [CrossRef]

31. Kuzmanić Samija, R.; Primorac, D.; Resić, B.; Lozić, B.; Krzelj, V.; Tomasović, M.; Stoini, E.; Samanović, L.; Benzon, B.; Pehlić, M.; et al. Association of NOS3 tag polymorphisms with hypoxic-ischemic encephalopathy. Croat. Med. J. 2011, 52, 396-402. [CrossRef]

32. Wu, Y.; Zhu, Z.; Fang, X.; Yin, L.; Liu, Y.; Xu, S.; Li, A. The Association between NOS3 Gene Polymorphisms and Hypoxic-Ischemic Encephalopathy Susceptibility and Symptoms in Chinese Han Population. BioMed Res. Int. 2016, 2016, 1957374. [CrossRef] [PubMed]

33. Weeke, L.C.; Groenendaal, F.; Mudigonda, K.; Blennow, M.; Lequin, M.H.; Meiners, L.C.; van Haastert, I.C.; Benders, M.J.; Hallberg, B.; de Vries, L.S. A Novel Magnetic Resonance Imaging Score Predicts Neurodevelopmental Outcome After Perinatal Asphyxia and Therapeutic Hypothermia. J. Pediatr. 2018, 192, 33-40.e32. [CrossRef] [PubMed]

34. Sarnat, H.B.; Sarnat, M.S. Neonatal Encephalopathy Following Fetal Distress: A Clinical and Electroencephalographic Study. Arch. Neurol. 1976, 33, 696-705. [CrossRef] [PubMed]

35. Rutherford, M.; Ramenghi, L.A.; Edwards, A.D.; Brocklehurst, P.; Halliday, H.; Levene, M.; Strohm, B.; Thoresen, M.; Whitelaw, A.; Azzopardi, D. Assessment of brain tissue injury after moderate hypothermia in neonates with hypoxic-ischaemic encephalopathy: A nested substudy of a randomised controlled trial. Lancet Neurol. 2010, 9, 39-45. [CrossRef]

36. Procianoy, R.S.; Corso, A.L.; Longo, M.G.; Vedolin, L.; Silveira, R.C. Therapeutic hypothermia for neonatal hypoxic-ischemic encephalopathy: Magnetic resonance imaging findings and neurological outcomes in a Brazilian cohort. J. Matern Fetal Neonatal Med. 2019, 32, 2727-2734. [CrossRef]

37. Martinez-Biarge, M.; Diez-Sebastian, J.; Rutherford, M.A.; Cowan, F.M. Outcomes after central grey matter injury in term perinatal hypoxic-ischaemic encephalopathy. Early Hum. Dev. 2010, 86, 675-682. [CrossRef]

38. Trivedi, S.B.; Vesoulis, Z.A.; Rao, R.; Liao, S.M.; Shimony, J.S.; McKinstry, R.C.; Mathur, A.M. A validated clinical MRI injury scoring system in neonatal hypoxic-ischemic encephalopathy. Pediatr. Radiol. 2017, 47, 1491-1499. [CrossRef]

39. Dupont, W.D.; Plummer, W.D., Jr. Power and sample size calculations. A review and computer program. Control. Clin. Trials 1990, 11, 116-128. [CrossRef]

40. Song, L.; Pei, L.; Yao, S.; Wu, Y.; Shang, Y. NLRP3 Inflammasome in Neurological Diseases, from Functions to Therapies. Front. Cell. Neurosci. 2017, 11, 63. [CrossRef]

41. Bai, Y.; Nie, S.; Jiang, G.; Zhou, Y.; Zhou, M.; Zhao, Y.; Li, S.; Wang, F.; Lv, Q.; Huang, Y.; et al. Regulation of CARD8 expression by ANRIL and association of CARD8 single nucleotide polymorphism rs2043211 (p.C10X) with ischemic stroke. Stroke 2014, 45, 383-388. [CrossRef]

42. McKinney, C.; Stamp, L.K.; Dalbeth, N.; Topless, R.K.; Day, R.O.; Kannangara, D.R.W.; Williams, K.M.; Janssen, M.; Jansen, T.L.; Joosten, L.A.; et al. Multiplicative interaction of functional inflammasome genetic variants in determining the risk of gout. Arthritis Res. Ther. 2015, 17, 288. [CrossRef]

43. Bagnall, R.D.; Roberts, R.G.; Mirza, M.M.; Torigoe, T.; Prescott, N.J.; Mathew, C.G. Novel isoforms of the CARD8 (TUCAN) gene evade a nonsense mutation. Eur. J. Hum. Genet. 2008, 16, 619-625. [CrossRef] [PubMed] 
44. Klen, J.; Goricar, K.; Janez, A.; Dolzan, V. NLRP3 Inflammasome Polymorphism and Macrovascular Complications in Type 2 Diabetes Patients. J. Diabetes Res. 2015, 2015, 616747. [CrossRef] [PubMed]

45. Roberts, R.L.; Topless, R.K.; Phipps-Green, A.J.; Gearry, R.B.; Barclay, M.L.; Merriman, T.R. Evidence of interaction of CARD8 rs2043211 with NALP3 rs35829419 in Crohn's disease. Genes Immun. 2010, 11, 351-356. [CrossRef] [PubMed]

46. Herman, R.; Jensterle, M.; Janez, A.; Goricar, K.; Dolzan, V. Genetic Variability in Antioxidative and Inflammatory Pathways Modifies the Risk for PCOS and Influences Metabolic Profile of the Syndrome. Metabolites 2020, 10, 439. [CrossRef]

47. McGovern, D.P.; Butler, H.; Ahmad, T.; Paolucci, M.; van Heel, D.A.; Negoro, K.; Hysi, P.; Ragoussis, J.; Travis, S.P.; Cardon, L.R.; et al. TUCAN (CARD8) genetic variants and inflammatory bowel disease. Gastroenterology 2006, 131, 1190-1196. [CrossRef]

48. Lv, J.; Jiang, X.; Zhang, J.; Peng, X.; Lin, H. Combined polymorphisms in genes encoding the inflammasome components NLRP3 and CARD8 confer risk of ischemic stroke in men. J. Stroke Cereb. Dis. 2020, 29, 104874. [CrossRef]

49. Fontalba, A.; Gutiérrez, O.; Llorca, J.; Mateo, I.; Berciano, J.; Fernández-Luna, J.L.; Combarros, O. Deficiency of CARD8 Is Associated with Increased Alzheimer's Disease Risk in Women. Dement. Geriatr. Cogn. Disord. 2008, 26, 247-250. [CrossRef]

50. Chen, Y.; Ren, X.; Li, C.; Xing, S.; Fu, Z.; Yuan, Y.; Wang, R.; Wang, Y.; Lv, W. CARD8 rs2043211 Polymorphism is Associated with Gout in a Chinese Male Population. Cell. Physiol. Biochem. 2015, 35, 1394-1400. [CrossRef]

51. Blomgran, R.; Patcha Brodin, V.; Verma, D.; Bergström, I.; Söderkvist, P.; Sjöwall, C.; Eriksson, P.; Lerm, M.; Stendahl, O.; Särndahl, E. Common genetic variations in the NALP3 inflammasome are associated with delayed apoptosis of human neutrophils. PLoS ONE 2012, 7, e31326. [CrossRef]

52. Uhlén, M.; Fagerberg, L.; Hallström, B.M.; Lindskog, C.; Oksvold, P.; Mardinoglu, A.; Sivertsson, Å.; Kampf, C.; Sjöstedt, E.; Asplund, A.; et al. Tissue-based map of the human proteome. Science 2015, 347, 1260419. [CrossRef] [PubMed]

53. Sjöstedt, E.; Zhong, W.; Fagerberg, L.; Karlsson, M.; Mitsios, N.; Adori, C.; Oksvold, P.; Edfors, F.; Limiszewska, A.; Hikmet, F.; et al. An atlas of the protein-coding genes in the human, pig, and mouse brain. Science 2020, 367, eaay5947. [CrossRef] [PubMed]

54. Watanabe, Y.; Fukui, N.; Muratake, T.; Amagane, H.; Kaneko, N.; Nunokawa, A.; Someya, T. Association study of a functional promoter polymorphism of the X-box binding protein 1 gene in Japanese patients with schizophrenia. Psychiatry Clin. Neurosci. 2006, 60, 633-635. [CrossRef] [PubMed]

55. Ospina, J.A.; Brevig, H.N.; Krause, D.N.; Duckles, S.P. Estrogen suppresses IL-1beta-mediated induction of COX-2 pathway in rat cerebral blood vessels. Am. J. Physiol. Heart Circ. Physiol. 2004, 286, H2010-H2019. [CrossRef]

56. Aly, H.; Khashaba, M.T.; El-Ayouty, M.; El-Sayed, O.; Hasanein, B.M. IL-1beta, IL-6 and TNF-alpha and outcomes of neonatal hypoxic ischemic encephalopathy. Brain Dev. 2006, 28, 178-182. [CrossRef]

57. Gabriel, M.L.; Braga, F.B.; Cardoso, M.R.; Lopes, A.C.; Piatto, V.B.; Souza, A.S. The association between pro- and anti-inflammatory cytokine polymorphisms and periventricular leukomalacia in newborns with hypoxic-ischemic encephalopathy. J. Inflamm. Res. 2016, 9, 59-67. [CrossRef]

58. Hall, S.K.; Perregaux, D.G.; Gabel, C.A.; Woodworth, T.; Durham, L.K.; Huizinga, T.W.; Breedveld, F.C.; Seymour, A.B. Correlation of polymorphic variation in the promoter region of the interleukin-1 beta gene with secretion of interleukin-1 beta protein. Arthritis Rheum. 2004, 50, 1976-1983. [CrossRef]

59. Wang, J.; Shi, Y.; Wang, G.; Dong, S.; Yang, D.; Zuo, X. The association between interleukin-1 polymorphisms and their protein expression in Chinese Han patients with breast cancer. Mol. Genet. Genomic Med. 2019, 7, e804. [CrossRef]

60. Kanemoto, K.; Kawasaki, J.; Miyamoto, T.; Obayashi, H.; Nishimura, M. Interleukin (IL)1beta, IL-1alpha, and IL-1 receptor antagonist gene polymorphisms in patients with temporal lobe epilepsy. Ann. Neurol. 2000, 47, 571-574. [CrossRef]

61. Papiol, S.; Molina, V.; Rosa, A.; Sanz, J.; Palomo, T.; Fañanás, L. Effect of interleukin-1beta gene functional polymorphism on dorsolateral prefrontal cortex activity in schizophrenic patients. Am. J. Med. Genet. B Neuropsychiatr. Genet. 2007, 144b, 1090-1093. [CrossRef]

62. Zhang, W.; Deng, X.W.; Tang, R.J.; Gu, J.R.; Wang, H. Association of the IL-1B rs1143623 Polymorphism and Cancer Risk: A Meta-Analysis. Genet. Test. Mol. Biomark. 2020, 24, 685-688. [CrossRef] [PubMed]

63. Babić Leko, M.; Nikolac Perković, M.; Klepac, N.; Štrac, D.; Borovečki, F.; Pivac, N.; Hof, P.R.; Šimić, G. IL-1ß, IL-6, IL-10, and $\mathrm{TNF} \alpha$ Single Nucleotide Polymorphisms in Human Influence the Susceptibility to Alzheimer's Disease Pathology. J. Alzheimers Dis. 2020, 75, 1029-1047. [CrossRef] [PubMed]

64. Loft, N.D.; Skov, L.; Iversen, L.; Gniadecki, R.; Dam, T.N.; Brandslund, I.; Hoffmann, H.J.; Andersen, M.R.; Dessau, R.B.; Bergmann, A.C.; et al. Associations between functional polymorphisms and response to biological treatment in Danish patients with psoriasis. Pharm. J. 2018, 18, 494-500. [CrossRef] [PubMed]

65. Piber, P.; Vavpetic, N.; Goricar, K.; Dolzan, V.; Kovac, V.; Franko, A. The influence of genetic variability in IL1B and MIR146A on the risk of pleural plaques and malignant mesothelioma. Radiol. Oncol. 2020, 54, 429-436. [CrossRef]

66. Walczak, M.; Lykowska-Szuber, L.; Plucinska, M.; Stawczyk-Eder, K.; Zakerska-Banaszak, O.; Eder, P.; Krela-Kazmierczak, I.; Michalak, M.; Zywicki, M.; Karlowski, W.M.; et al. Is Polymorphism in the Apoptosis and Inflammatory Pathway Genes Associated with a Primary Response to Anti-TNF Therapy in Crohn's Disease Patients? Front. Pharmacol. 2020, $11,1207$. [CrossRef]

67. Martinez-Biarge, M.; Diez-Sebastian, J.; Kapellou, O.; Gindner, D.; Allsop, J.M.; Rutherford, M.A.; Cowan, F.M. Predicting motor outcome and death in term hypoxic-ischemic encephalopathy. Neurology 2011, 76, 2055-2061. [CrossRef]

68. Tsai, S.J. Effects of interleukin-1beta polymorphisms on brain function and behavior in healthy and psychiatric disease conditions. Cytokine Growth Factor Rev. 2017, 37, 89-97. [CrossRef] 
69. Gromadzka, G.; Kruszynska, M.; Wierzbicka, D.; Litwin, T.; Dziezyc, K.; Wierzchowska-Ciok, A.; Chabik, G.; Czlonkowska, A. Gene variants encoding proteins involved in antioxidant defense system and the clinical expression of Wilson disease. Liver Int. 2015, 35, 215-222. [CrossRef]

70. Rajaraman, P.; Hutchinson, A.; Rothman, N.; Black, P.M.; Fine, H.A.; Loeffler, J.S.; Selker, R.G.; Shapiro, W.R.; Linet, M.S.; Inskip, P.D. Oxidative response gene polymorphisms and risk of adult brain tumors. Neuro Oncol. 2008, 10, 709-715. [CrossRef]

71. Sochocka, M.; Diniz, B.S.; Leszek, J. Inflammatory Response in the CNS: Friend or Foe? Mol. Neurobiol. 2017, 54, 8071-8089. [CrossRef]

72. Tagin, M.A.; Woolcott, C.G.; Vincer, M.J.; Whyte, R.K.; Stinson, D.A. Hypothermia for neonatal hypoxic ischemic encephalopathy: An updated systematic review and meta-analysis. Arch. Pediatr. Adolesc. Med. 2012, 166, 558-566. [CrossRef] [PubMed] 